2. Demydov A.M. Osoblyvosti zhyttiediialnosti nepovnykh simei. Simia i sotsialna struktura. Moskva, 1987. $234 \mathrm{~s}$.

3. Doktorovych M.O. Sotsialno-pedahohichna robota $z$ ditmy $z$ nepovnykh simei: navch.-metod. posibnyk dlia stud. VNZ. Kyiv: Lenvit, 2010. $152 \mathrm{~s}$.

4. Zemska M.V. Semia y lychnost: per. s polskoho L.V.Vasyleva / Obshch. red., poslesl. M. S. Matskovskoho. Moskva: Prohress, 1986. $133 \mathrm{~s}$.

5. Kovbas B.I., Kostiv V.I. Rodynna pedahohika: U 3-kh t. Tom 1. Osnovy rodynnykh vzaiemovidnosyn / red. B.I. Kovbasa, V.I. Kostiva. Ivano-Frankivsk: Plai, 2002. 288 s.

6. Kostyv V.Y. Vnebrachnaia semia. Nepolnaia semia. Osyrotevshaia semia. Pryemnyie dety. Semeinoe vospytanye: kratkyi slovar. Moskva: Polytzdat, 1990. 206 s.

7. Kostiv V.I. Kharakterystyka moralnoho protsesu u systemi tsinnisno-normatyvnoi rehuliatsii povedinky osoby: Zbirnyk naukovykh prats: filosofiia, sotsiolohiia, psykholohiia / Za red. S.Vozniak, L. Orban. Ivano-Frankivsk, 1996. Ch.2. S.96-105.

8. Kostiv V. Konsultatyvna robota $z$ problem rodynnoho vykhovannia u nepovnii simi. Seriia "Pedahohika, etnopedahohika". Vypusk 24. Ivano-Frankivsk, 1998. $116 \mathrm{c}$

9. Ratter M. Pomoshch trudnyim detiam: per. s anhl. / Obshch. red. A. S.Spyvakovskoi; predysl. O. V. Bazhenovoi y A. Ya. Varha. Moskva: Prohress, 1987. $424 \mathrm{~s}$.

10. Sotsialna robota $\mathrm{v}$ Ukraini: teoriia ta praktyka. Posibnyk dlia pidvyshchennia kvalifikatsii pratsivnykiv sotsialnykh sluzhb dlia molodi. / Za zah. red. dots. A. Ya. Khodorchuk . Kyiv, 2003. $272 \mathrm{~s}$.

Одержано статтю: 11.07.2019

Прийнято до друку: 25.07.2019

УДК 159.9.01

DOI: 10.15330/esu. 16.174-181

\section{Світлана Литвиненко,}

доктор педагогічнах наук, професор,

Рівненський державний гуманітарний

Університет (м. Рівне, Україна)

Svitlana Lytvynenko,

Doctor of pedagogical sciences, Professor,

Rivne state humanitarian the university

(Rivne, Ukraine)

sa.litv50@gmail.com

\title{
ФЕНОМЕНОЛОГІЯ ГРИ ТА ІГРОВӦ̈ ДІЯЛЬНОСТІ: СУЧАСНІ ПІДХОДИ
}

\section{PHENOMENOLOGY OF GAME AND GAME ACTIVITIES: MODERN APPROACHES}

У статті здійснено аналіз досліджень феномену гри в сутнісно-буттєвому вимірі та розкрито провідні підходи щодо визначення сутності, ознак, особливостей та функиій гри. Доведено, ио гра є природним, органічним елементом та витвором людської культури, закономіриим результатом еволючій, ио засвідчус ї̈ приналежність до ефективних засобів особистісного розвитку та сочіалізаџії людини, засвоєння нею смислів, культурних норм $і$ традицій. До провідни характеристик гри належать: свобода, спонтанність $i$ активність, тобто діяльність позбавлена управління й програмування; взаємодія $з$ використанням різних предметів і засобів (матеріальних та не матеріальних), наповненість практичними діями й рухливістю; відсутність прагматичних цілей та результатів; пережсивання приємних емоџій та задоволення, пов 'язаних з самим прочесом грu.

Ключові слова: феномен гри, гра, ознаки і функиії гри.

The article analyzes the research of the phenomenon of the game in the essence-existential dimension. The leading philosophical, culturological and psychological approaches to the definition of the essence of the game are presented. It is proved that the game is a natural, organic 
element and a product of human culture, a natural result of evolution, which testifies to its belonging to the effective means of personal development and human socialization.

The author determined the features of the game, among which: freedom, spontaneity and activity, that is, activity which is deprived of control and programming; interaction with the use of various objects and means (material and nonmaterial), filled with the practical actions and mobility; lack of pragmatic goals and results, since it is carried out for the gaming activity; feeling pleasant emotions and pleasures associated with the game process.

The functions of the game (dramatic, cathartic and compensatory functions, formation and development of social skills, etc.) are revealed, which determine its use in psychological and pedagogical practice. The requests for scientific understanding of not only positive meanings and functions of the game, but also its risk-taking aspects are substantiated.

Key words: the phenomenon of the game, game, game features and functions.

Постановка проблеми. Коло питань щодо природи й сутності гри, динаміки ii характеру, місця і ролі в сучасному суспільстві, можливостей в соціалізації й розвитку людини постійно розширюється. Різноманітним і барвистим є буття гри та широта вжитку цього поняття в міркуваннях про життя й позначення багатьох соціально-культурних явищ. Вивчення феноменології гри відкриває широкі можливості завдяки багатогранності та синтетичній природі ігрової діяльності, яка обіймає різноманітні види й форми людської активності. Семантика слова "гра" розгортається від позначення: дитячої чи спортивної гри, гри на музичних інструментах й акторів на сцені, політичних ігор сучасності й ігрових моделей для відпрацювання стратегії поведінки, а також характеристики управлінської та посередницької діяльності тощо). Свідомо чи несвідомо звертаємося до гри в серйозних особистісних темах (“ігри розуму”), і навіть таких, як смерть (“смертельна гра" чи “гра зі смертю"). Проблематика, пов'язана з категорією гри, увійшла в сучасний онтологічний дискурс, що дозволило з різних наукових позицій звернутися до осягнення сутності гри в і1ї нерозривному зв'язку із життям.

Аналіз філософської, культурологічної та психолого-педагогічної літератури засвідчує, що феномен гри привертав увагу представників різних галузей науки як складний, глибокий та багатогранний соціально-культурний та особистісний феномен. Філософи і письменники в усі часи намагалися дослідити та осягнути природу й таємничу принадність гри, глибинний духовний смисл їі творчого проживання, в якому народжується новий досвід. Гра завжди спонукала до нових пошуків та відкриттів. Влучно, із захопленнням та іронією В. Шекспір підмітив "сцену життя" i “світ - театр", у якому - усі актори. Ігри визнано однісю із найважливіших життєвих потреб, що еволюціонувала разом з людиною й втілилася в багатстві й розмаїтті форм (дитячі, спортивні, ділові, ритуальні, військові, пізнавальні, проблемні, дослідницькі тощо), які дозволили краще пристосовуватися до потреб середовища, праці, наукової та художньої творчості.

Мета статті полягає у здійсненні аналізу досліджень феномену гри в сутнісно-буттєвому вимірі та вивченні провідних підходів щодо визначення сутності, ознак, особливостей та функцій гри.

Аналіз основних досліджень і публікацій. У зверненні до феноменології гри сучасна наука спирається на історично сформовані теоретичні надбання попередніх епох. Спроби пізнання гри сягають глибокої давнини i беруть витоки 3 часів зародження філософської думки. Про божественну гру як спосіб створення та існування світу розмірковували Геракліт і Платон. У часи розвитку філософії гуманізму i епоху Просвітництва звернулися до виховного та розвивального 
потенціалу гри Я. А. Коменський, Д. Локк, М. Монтень, І. Г. Песталоцці, Ф. Рабле, Ж.-Ж. Руссо, Г. Спенсер та ін.

Сучасні дослідження різних аспектів феномену гри здійснюються в багатьох напрямах: вивчення філософьких і соціально-культурних засад гри (М. Бахтін, В. Біблер, І. Бех, І. Кон, Г. Клаус, Ю. Лотмана, М. Мамардашвілі, М. Мід, Е. Фінк, Й. Хейзінга та ін.); психолого-педагогічної сутності ігрової діяльності (Л. Артемова, П. Блонский, А. Богуш, Л. Божович, Ш. Бюллер, Л. Виготський, С. Кулачківська, Ж. Піаже, Л. Піроженко, С. Рубінштейн, С. Русова, В. Сухомлинський, Ф. Фребель та ін.); вивчення організаційно-діяльнісних ігор і можливостей гри в освітній та виробничо-економічній сфері (М. Бірштейн, Ю. Кравченко, К. Фопель, А. Фурман, Г. Щедровицький та ін.). Австрійський логік, філософ і лінгвіст Л. Вітгенштейн створив ігрову теорію походження і функціонування мови, а німецький філософ Г. Клаус виявив ігровий аспект військової діяльності і довів значущість гри у становленні кібернетики. Відтак, онтологічний аналіз гри, питання їі співвідношення 3 буттям, актуалізують вивчення взаємозв'язків наукової теорії і безпосередньої життєвої практики. Для філософського та психолого-педагогічного аналізу важливим $€$ дослідження сутності та значення гри як феномену буття й провідної діяльності, специфічної форми взаємодії і спілкування людини.

Виклад основного матеріалу. Протягом кількох століть вивчення гри було прерогативою філософів, однак за цей період сформувалася база сучасного не тільки філософського, але й культурологічного, психолого-педагогічного розуміння гри та ігрової діяльності. Уважається, що долучення гри до предметного простору філософського знання закладено німецькими філософами Іммануїлом Кантом (17241804) та Фрідріхом Шіллером (1759-1805), які звернули увагу на подібність між грою i художньою діяльністю. Саме I. Канту було властиве розуміння гри як особливого вільного душевного стану й форми вільного часу $[2 ; 3 ; 6]$.

У такому розумінні гри близькими до поглядів І. Канта були позиції К. Гроса й Ф. Шіллера, що поєднали розуміння гри й естетики. Так, Ф. Шіллер пов’язував гру 3 насолодою, вільним проявом надлишку сил, а Г. Спенсер убачав походження гри 3 внутрішньої потреби в діяльності як форми вправляння, зміцнення i розвитку спадкових форм поведінки. Такої ж позиції дотримувався і К. Грос, розглядаючи гру переважно 3 біологічних позицій як вправляння природних нахилів. 3 нашого погляду, на ці ідеї спирається психологія дитячої ігрової діяльності, визнаючи, що в системі культури гра слугує одним із засобів емоційно насиченою комунікації, розвитку і первинної соціалізації, сприяючи входженню нового покоління в людське суспільство $[1 ; 6]$.

У подальшому найбільш відоме дослідження гри, здійснене у XX столітті голандським філософом та істориком культури Йоханом Хейзінгою (Нuizinga, 18721945) у роботі "Ноmo ludens" (“Людина, що грає”), опублікованій у 1938 році, яка виявила істотний вплив на подальші розробки проблеми. Дослідник пояснював соціокультурний феномен гри, виходячи 3 принципу, що гра $є$ старшою, ніж культура. Так, до естетичного і вільного розуміння гри, розробленого I. Кантом і Ф. Шіллером, додалася ще одна їі функція - збереження і зародження культури.

Пізніше німецькі філософи звернулися до вивчення сутнісних особливостей феномена гри, іï місця й цілей у житті людини. Так, Ханс-Георг Гадамер (Gadamer) в роботі “Істина і метод” (1960) поширив й долучив поняття гри до змістового апарату герменевтики (теорії розуміння і тлумачення), а німецький мислитель Ойген Фінк (Eugen Fink, 1905-1975) визнав гру як один із феноменів людського буття. Розробку 
концепції ігрової генези культури, створену Й. Хейзінгою, було продовжено в доробках О. Фінка. Водночас незважаючи на відмінності в поглядах дослідників, які радше є взаємодоповнюючими, аніж суперечливими, ними було визнано буттєві характеристики гри, яка обіймає людську культуру і посідає важливе місце в іï становленні та існуванні [6].

У доробку Й. Хейзінги розкрито дефініцію гри як добровільної дії або заняття, що здійснюється згідно внутрішньо встановлених меж місця i часу, добровільно прийнятих, але абсолютно обов'язкових правил з метою, закладеною в ній самій, що супроводжується почуттям напруження і радості, а також свідомістю "іншого", ніж "буденне" життя. При цьому Й. Хейзінга не приховує пафосу і свого захоплення 3 приводу сакрального значення гри: “Буття гри повсякчас підтверджує, причому в найвищому смислі, супралогічний характер нашого положення у Всесвіті... Ми граємося, і ми знаємо, що ми граємося, значить, ми є чимось більшим, ніж лише розумні істоти, оскільки гра $є$ заняттям позарозумним" [11, с. 13$]$.

Близьку, але 3 іншими акцентами дефініцію представлено в дослідженні К. Сігова, що визначає гру як форму вільного самовияву людини, що передбачає реальну відкритість світу можливого і розгортається або у вигляді змагання, або ж у вигляді подання (виконання, репрезентації) будь-яких ситуацій, смислів і станів [7].

У сучасному Новітньому філософському словнику гра тлумачиться як різновид фізичної та інтелектуальної діяльності, позбавлений практичної доцільності, що надає індивіду можливості самореалізації, яка виходить за межі його актуальних соціальних ролей. При цьому зауважується, що цінність гри полягає не в іiі результаті, а в самому ігровом процесі [9, с. 798].

Водночас, О. Фінк, наголошував, що дати універсальне визначення гри неможливо, оскільки гра є екзістенційним феноменом, який відштовхує від себе поняття. Дослідник визнав, що гра є одним із способів розуміння, за допомогою яких людина розуміє себе й прагне через такі смислові горизонти пояснити буття всіх речей. О. Фінк поставив гру в один ряд 3 такими феноменами, як смерть, праця, любов [10]. На думку Х.-Г. Гадамера, суб'єктом гри $\epsilon$ не той, хто грає, а сама гра, i це вочевидь виявляється, коли людина грає на самоті, адже ніхто інший, крім гри, не визначає й не обумовлює поведінку [5].

Звернемося до більш докладного розгляду та розкриття, презентованих у дефініціях та дослідженнях ознак та особливостей гри. Згідно Йохана Хейзінги гра постає як діяльність, що активно здійснюється заради неї самої $\mathrm{i}$ в ході цього наповнюе радістю. До провідних характеристик гри 3 таких позицій належать: свобода, спонтанність і активність, тобто діяльність позбавлена управління й програмування; взаємодія з використанням різних предметів і засобів (матеріальних та не матеріальних), наповненість практичними діями й рухливістю; відсутність прагматичних цілей та результатів, оскільки здійснюється заради самої ігрової діяльності; переживання приємних емоцій та задоволення, пов'язаних 3 самим процесом гри.

Свобода у грі виявляється, передусім, як незалежність від необхідності чи примусу, оскільки, згідно Й. Хейзінги, гра за наказом не може бути в повному сенсі грою, а лише імітацією, репродукцією гри. Також під свободою у грі дослідник розуміє й "неінстинктивну" обумовленість поведінки гравців. Ігри, скеровані інстинктами, не набувають повноти ігрової природи (немовлята і дитинчата тварин ще не володіють такою свободою). Однак можна стверджувати, що діти і тварини граються задля радості, коли відчувають задоволення - і в цьому полягає їхня 
свобода. Саме процес гри надає можливості творчої самореалізації, що виходить за межі актуальних соціальних ролей й дозволяє особистості стати суб'єктом життєдіяльності. Пережита як природне буття й різновид вільної фізичної і інтелектуальної діяльності, гра постає невід'ємним атрибутом життя людини, способом пізнання дійсності і самопізнання, реалізації “природних сутнісних сил”. Одна з вагомих особливостей, поміченех ще Ф. Шіллером - $\epsilon$ творення у грі самого себе. Відзначимо, що й залежність від гри - це теж певною мірою $є$ творенням образу себе.

Свобода гри виявляється як незалежність від утилітарних цілей, безпосереднього матеріального інтересу й моральних зобов'язань. Тому будь-яка гра в певному сенсі $\epsilon$ безцільною, оскільки досягнення результату як “об'єктивного факту" в ній несуттєве, не приносить задоволення ні біологічної потреби, ні створення певної утилітарною цінності. Коли ж грають тільки заради вигоди, то втрачається сутнісне значення гри, оскільки справжній гравець грає тільки для того, щоб грати. Згідно Й. Хейзінги, якщо люди грають, значить, вони є чимось більшим, ніж розумні істоти, поведінка яких підпорядковується лише раціональності, адже гра раціональністю не обмежується. Ще однією особливістю гри $є$ іï здатність руйнування стереотипів й вивільнення людини від гніту буденності, збагачення творчих здібностей і забезпечення умов для самовияву. Саме завдяки грі засвоюються загальні смисли буття та людської діяльності, а не іiі операційно-технологічний бік, як у навчанні й праці.

Виразною ознакою будь-якої гри є подвійність (Т. Апінян, А. Демидова, Й. Хейзінга, Ж. Піаже та ін.), що реалізується на межі двох світів: як діяльність, що одночасно розгортається в реальності і в уявному світі. Навіть маленька дитина не плутає ігровий та реальний світи. Втручання реального світу може порушити гру, оскільки дитина усвідомлює їх відмінності (наприклад, у грі з лялькою дівчинка, не плутає ляльку 3 живою істотою). Характеристика гри як ілюзорного світу не виключає й серйозності, оскільки несерйозне ставлення до гри, ігнорування іiі правил спотворює й руйнує гру. Справжня гра пов'язана з натхненням і може підніматися до вершин духовного, полишаючи серйозність буденності. Згідно Й. Хейзінги справжня гра не є “дитячістю”, якщо ж дитина виявляє дитячість, то вона більше не хоче гратися або не знає, у що, і як саме гратися. Так, коли б діти, спортсмени або артисти почали несерйозно ставитися до того, що роблять, гра припинилася б або ж перетворилася на пародію чи абсурд.

У плинності й сумбурності буденності будь-яка гра створює певну тимчасову досконалість зі своїми особливими правилами, оскільки володіє структурною впорядкованістю й завершеністю (має початок і кінець), відбувається в певних межах простору і часу, у яких існує “ігровий світ". Таким ігровим простором може виступати арена цирку й сцена, кінозал і дитяча пісочниця тощо. Сама гра встановлює обмеження у вигляді правил, навіть невелике відхилення від її порядку є руйнівним, а дія, доречна в певних умовах, за межами ігрового простору виглядає кумедною або перетворюється на епатаж. Поширений вислів “гра без правил” не має буквального сенсу, а в переносному - вказує на хаотичність і безлад. Зазвичай підміна справжньої гри стається, коли гравці діють заради власної мети, ігноруючи норми взаємодії з іншими.

Структура, як ознака гри, забезпечує одночасну варіативність й мінливість дій у певних межах. Так, майже у всіх розвинених формах колективних дитячих ігор наявні елементи повтору, рефрену й ритуалу. Можливість відтворення дитячих ігор 
перетворює їх на культурну цінність, яка передається як традиція. А варіативність, що також заснована на структурі, надає грі творчості й свободи, без яких гра перетворюється на бездушну роботу, стереотип. У випадку передбачуваного й наперед відомого результату зникає саме ігрове начало, а ризик та свобода рішення, варіативність можливостей надають грі чарівності й захоплення. Структурна впорядкованість дозволяє поринати у гру i позбавляє від тривог, властивих повсякденному "неорганізованому" життю, активізує спонтанне прагнення людини до повторення й відновлення гри. Такі переживання знайомі тим, хто грає 3 комп'ютером, вирішує цікаві завдання, пробує писати вірші чи малювати тощо. У всіх випадках існує ризик, що справа може "не скластися", водночас це активізує захоплення, азарт, сподівання домогтися успіху [6].

Дослідниками (Т. Апінян, Л. Бєлоглазова, А. Демидов, Е. Патраков та ін.) відзначено особливе місце елементу напруги, що виявляється у грі, й зумовлює невизначеність та нереалізовані можливості (комп'ютерні ігри, головоломки, квести, тощо). Напруга зростає, коли гра набуває змагальності й азарту, а найвищого ступеня досягає у спорті. Ігрова напруга гартує силу й витримку, наполегливість й винахідливість, витривалість та відвагу, а поряд із тим розвиваються й моральнодуховні якості. На думку О. Фінка, напруга у грі відрізняються від турбот повсякденного життя, оскільки в буденності притаманне прагнення до майбутнього задоволення і певного невизначеного “шастя”. Хоча гра так само спонукає до успіху, однак задоволення знаходиться в ній самій, тобто гра не виходить за свої межі й дарує їі учасникам “насолоду теперішнього моменту" [10].

Натхнення і звільнення, яке дарує людині гра, співвідносне поняттю “катарсису" (очищення), до якого зверталися ще у стародавній філософії. Піфагорійці практикували очищення душі за допомогою спеціально дібраної музики, а Арістотель у своїй "Поетиці" довів, що катарсис стається навіть при перегляді трагедії в театрі (через співпереживання героям стається очищення душ глядачів від афектів). Неважко помітити, що виявлений античними філософами катарсичний вплив, властивим також і грі. У зв'язку з чим використання ігрових методів в умовах сьогодення $\epsilon$ складовою практично будь-якої психолого-педагогічної допомоги [8].

Здійснений аналіз наукових джерел (Т. Апінян, Л. Бєлоглазова, А. Демидов, Е. Патраков та ін.) дозволяє звернутися до сутнісних функцій гри, які визначають їі використання у психолого-педагогічній практиці. Реалізація ігрової функції одержання задоволення та свободи самовияву забезпечує ефективність психологопедагогічної допомоги дорослим і дітям у випадках широкого спектру невротичних розладів та проявів дезадаптивної поведінки. Гра володіє також компенсаторною функцією як засобом підтримки гармонії всебічного розвитку особистості, тобто того, що людина не може досягти в житті, реалізується в ігровій формі. Водночас слід звернутися й до психологічної ризикогенності у випадках активізації цих функцій у поєднанні 3 інфантилізацією, що зумовлює можливості формування ігрової залежності. Однак у дослідженнях засвідчено, що найбільш ефективним антагоністом може виступати активізація продуктивної зайнятості й просоціальної активності в цілому. Формування й розвиток соціальних навичок як значима функція, позбавлена подібних ризиків, яка реалізується у всіх видах інтенсивних освітніх корекційних i реабілітаційних програм незалежно від віку. Дотична їй функція гри як ритуалу або культу, що у практиці психологічної допомоги виявляється радше як необхідність дезактивізації при певних обсесивно-компульсивних розладах, оскільки послаблення нав'язливої поведінки та значення ритуалу 
для особистості виявляється більш ефективним поряд з формуванням нових успішних соціальних навичок. Привертає увагу катарсична й драматична функція гри, що можуть бути реалізована у психотерапевтичній та психолого-педагогічній практиці.

Висновки. Здійснений аналіз феномену гри переконливо доводить, що гра $є$ природним, органічним елементом та витвором людської культури, закономірним результатом еволюції, що засвідчує іiі приналежність до ефективних засобів особистісного розвитку та соціалізації людини, засвоєння нею смислів, культурних норм і традицій. Хоча для феномену гри властива універсальна природа, однак їі розмаїття й багатоплановість форм розглядалися в науковому вимірі з різних істотно несуперечливих позицій. Основою, присвяченого грі сучасного наукового дискурсу, постає запропонована Й. Хейзінгою формула homo ludens - людина граюча, що додає до багатьох людських образів ще один, навіть досить епатажний. Зміст формули hото ludens привертає до феномену гри як суттєвої характеристики людського буття, особливо в ситуації “ігрового апокаліпсису” (Л. Бєлоглазова). У зв'язку з чим метафора "життя - це гра" втрачає метафоричність і перетворюється в життєвосмисловий орієнтир. Постала необхідність наукової рефлексії сучасних тенденцій відриву людини від буттєвих засад, що зумовлюють соціальне відчуження, спрощення й нівелюванням буття до ігрового видовища, гедонізацію ігрового процесу та віртуалізацію свідомості дорослих та дітей. Усе це визначає запити щодо звернення не тільки до позитивних смислів і функцій гри, але й іï ризикогенних аспектів.

\section{Література}

1. Апинян Т.А. Сущностно-универсальное определение игры: феноменология фантома / Т. Апинян // Вопросы философии. - 2008. - № 2. - С. 59 - 73.

2. Білик Я.М. Ігровий феномен в культурі : автореф. на здобуття наукового ступеня докт. філос наук: 09.00.04 - філософська антропологія і філософія культури / Я. Білик. - Х., 1999. - 26 с [21].

3. Белоглазова Л.А. К проблеме игры / Л. А. Белоглазова // Философия и будущее цивилизации. Тезисы докладов и выступлений IV философского конгресса T. 4 - М.: Современные тетради, $2005-$ C. $23-24$

4. Берлянд И. Е. Игра как феномен сознания / И. Е. Берлянд. - Кемерово: “Алеф”. Гуманитарный центр, 1992. - $94 \mathrm{c}$.

5. Гадамер Г.-Г. Істина і метод: [пер. з нім.] / Г.-Г. Гадамер. - К.: Юніверс, 2000. - Т.1. - 464 с

6. Демидов А.Б. Феномены человеческого бытия / А.Б. Демидов. - Мн.: Издательский центр ЗАО "Экономпресс", 1999.- 325 с.

7. Новейший философский словарь / Сост. А.А. Грицанов.- Мн.- Из-во В.М. Скакун.- 1998.

8. Патраков Э.В. Философские основы применения игры в практике психологической помощи: [режим доступу] https://cyberleninka.ru/article/n/filosofskie-osnovy-primeneniya-igry-v-praktikepsihologicheskoy-pomoschi.

9. Сигов К. Человек вне игры и человек играющий / К. Сигов // Философия и социологическая мысль. - 1990. - № 4. - С. $31-47$.

10. Финк О. Основные феномены человеческого бытия / О. Финк // Проблемы человека в западной философии. - М.: 1988. - С. 357-402.

11. Хейзинга Й. Homo Ludens. В тени завтрашнего дня / Й. Хейзинга. - М.: Прогресс - Академия, 1992. -464 c.

\section{References}

1. Apynian T.A. Sushchnostno-unyversalnoe opredelenye yhryi: fenomenolohyia fantoma / T. Apynian // Voprosyi fylosofyy. - 2008. - № 2. - S. $59-73$.

2. Bilyk Ya.M. Ihrovyi fenomen v kulturi : avtoref. na zdobuttia naukovoho stupenia dokt. filos. nauk: 09.00.04 - filosofska antropolohiia i filosofiia kultury / Ya. Bilyk. - Kh., 1999. - 26 s [21].

3. Belohlazova L.A. K probleme yhryi / L. A. Belohlazova // Fylosofyia y budushchee tsyvylyzatsyy. Tezysyi dokladov y vyistuplenyi IV fylosofskoho konhressa T. 4 - M.: Sovremennyie tetrady, $2005-$ S. 23-24 
4. Berliand Y. E. Yhra kak fenomen soznanyia / Y. E. Berliand. - Kemerovo: "Alef". Humanytarnyii tsentr, 1992. $-94 \mathrm{~s}$.

5. Hadamer H.-H. Istyna i metod: [per. z nim.] / H.-H. Hadamer. - K.: Yunivers, 2000. - T.1. - $464 \mathrm{~s}$.

6. Demydov A.B. Fenomenyi chelovecheskoho byityia / A.B. Demydov. - Mn.: Yzdatelskyi tsentr ZAO "Эkonompress", 1999.- $325 \mathrm{~s}$.

7. Noveishyi fylosofskyi slovar/Sost. A.A. Hrytsanov.- Mn.- Yz-vo V.M. Skakun.- 1998.

8. Patrakov Э.V. Fylosofskye osnovyi prymenenyia yhryi v praktyke psykholohycheskoi pomoshchy: [rezhym dostupu] https://cyberleninka.ru/article/n/filosofskie-osnovy-primeneniya-igry-v-praktikepsihologicheskoy-pomoschi.

9. Syhov K. Chelovek vne yhryi y chelovek yhraiushchyi / K. Syhov // Fylosofyia y sotsyolohycheskaia myisl. - 1990. - № 4. - C. $31-47$.

10. Fynk O. Osnovnyie fenomenyi chelovecheskoho byityia / O. Fynk // Problemyi cheloveka v zapadnoi fylosofyy. - M.: 1988. - S. 357-402.

11. Kheizynha Y. Homo Ludens. V teny zavtrashneho dnia / Y. Kheizynha. - M.: Prohress - Akademyia, 1992. $-464 \mathrm{~s}$.

Одержано статтю: 08.08.2019

Прийнято до друку: 22.08.2019

УДК 378.034/.037

DOI: $10.15330 /$ esu. $16.181-186$

\section{Ірина Сопівник,}

доктор педагогічних наук, доцент,

Національний університет біоресурсів і природокористування України (м. Київ, Україна)

Iryna Sopivnyk,

Doctor of pedagogical sciences, Associate Professor, National University of Life and Environmental Sciences of Ukraine (Kyiv, Ukraine) sopivnyk_i@nubip.edu.ua

\section{Вікторія Мацола,}

студентка, Національний університет біоресурсів і природокористування України (м. Київ, Україна)

\section{Viktoriia Matsola,}

student, National University of Life and

Environmental Sciences of Ukraine (Kyiv, Ukraine)

vika_9903@ukr.net

\section{МОНІТОРИНГ ЦІННІСНИХ ОРІЕНТАЦІЙ СУЧАСНОЇ МОЛОДІ}

\section{MONITORING OF VALUABLE ORIENTATIONS OF MODERN YOUTH}

У статті подано результати моніторингу иіннісних орієнтацій сучасних українських стариокласників та студентів. Висвітлено особливості иіннісної сфери юнаків, иџо обумовлені як специфікою віку, так і ціннісними оріснтирами украйнського суспільства загалом. Встановлено, ио для сучасної учнівської та студентської молоді найбільи важливими (у порядку спадання) с такі иінності як: освітні; життсвоважливі; пов'язані із самоствердженням; родинні; професійні; сочіальні; матеріальні; ігрові; пов 'язані з владою; конформістичні.

Ключові слова: ұінність, чіннісні орієнтації, чіннісна сфера особистості, аксіологічний підхід, молодь, моніторинг.

The article presents the results of the monitoring of value orientations of modern Ukrainian high school students and students. The features of the value sphere of young men are highlighted, which are caused both by the specifics of age and the value orientations of Ukrainian society as a whole. It has been established that for modern students and young people the most 